УДК 331.5

DOI: https://doi.org/10.37320/2415-3583/11.15

Плисенко Г.П.

кандидат економічних наук, Інститут підготовки кадрів державної служби зайнятості України

ORCID: https://orcid.org/0000-0003-0561-0732

\title{
ПІДПРИЕМНИЦЬКА ДІЯЛЬНІСТЬ ЖІНОК В УКРАЇНІ ТА СВІТІ ЯК ЕЛЕМЕНТ ТРАНСФОРМАЦІЇ ЯКОСТІ ТА СТРУКТУРИ РОБОЧОЇ СИЛИ
}

У статті висвітлено питання щзодо підприємницької діяльності жінок в Україні, проаналізовано та узагальнено сучасні умови ведення бізнесу та можливості відкриття власної справи. Розглянуто статистичні дані підприємницької діяльності серед жінок у деяких зарубіжних країнах. Дослідження сучасних тенденцій підприємницької діяльності жінок в Україні надали підстави обтрунтувати мотиви до започаткування бізнесу. Встановлено, шо сучасні умови ведення бізнесу в Україні характеризуються несприятливістю фіскальної, грошово-кредитної та регуляторної політики держави. Доведено, шүо участь жінок у бізнесі трансформує якість і структуру робочої сили та суспільства загалом, сприяє розвитку кар'єри жінок, самореалізації та створенню нових робочих місиь. Це впливає на їхні домогосподарства і громади, формування мислення майбутніх поколінь, які можуть спонукати до самозайнятості як природного варіанту кар'єри.

Ключові слова: жінки, підприємництво, бізнес, ринок праиі, зайнятість, служба зайнятості.

Постановка проблеми. Сучасні умови ведення бізнесу в Україні характеризуються несприятливістю фіскальної, грошово-кредитної та регуляторної політики держави, що негативно відображається на рівні конкурентоспроможності вітчизняних підприємств на внутрішніх i зовнішніх ринках (проблематика загострюється в умовах євроінтеграції України) [4]. Рівень підприємницької діяльності в Україні залишається недостатнім, навіть 3 урахування численних дій у сфері поліпшення діяльності підприємницьких структур, i потребує подальшого покращення [9]. Уряд України ставить за мету трансформувати національну економіку до соціально-орієнтованої, тому підтримка та активні дії з боку державних органів необхідні для забезпечення іï ефективної зміни. 3 огляду на те, що ринок праці є одним з основних складових елементів економіки, ця трансформація охопить i його та стане суттєвим чинником досягнення стабільного функціонування сфери зайнятості.

Чи не найактуальнішими $є$ питання щодо вдосконалення механізму та ефективності працевлаштування безробітних, передусім жінок. Однією iз активних форм підтримки безробітних, яка здійснюється державною службою зайнятості (далі - Служба) у разі відсутності на ринку праці належної роботи, є залучення безробітних до організації підприємницької діяльності. Участь жінок у бізнесі трансформує якість і структуру робочої сили та суспільства загалом, сприяє розвитку кар'єри жінок, самореалізації та створенню нових робочих місць. Це впливає на їхні домогосподарства і громади, формування мислення майбутніх поколінь, що може спонукати до самозайнятості як природного варіанту кар'єри. Жіноче підпри- ємництво потребує належної уваги з боку Уряду та суспільства загалом. Жінки є суттєвим потенціалом у сфері зайнятості, розкриття якого може реалізуватися завдяки навчанню і підтримці, що $€$ одним із ключових чинників для посилення їхньої ділової активності. Це може покращити економічну ефективність зайнятості та забезпечити створення нових робочих місць.

Аналіз останніх досліджень і публікацій. Дослідженням розвитку підприємницької діяльності в Україні присвячена велика кількість наукових праць. Такі вчені, як Л. Шваб, С. Мочерний, В. Колот у своїх роботах розглядали функції підприємництва, категорійний апарат підприємницької діяльності. Д. Бутенко, Ю. Довгопола [2] досліджували специфічні риси господарювання в Україні, рівень сприятливих умов ведення бізнесу в Україні. Основні проблеми розвитку підприємства в Україні розглядали О. Скорук [9], В. Щербак, Л. Ганущак та інші. Підприємництво в умовах євроінтеграційних процесів досліджували Ю. Сагайдак [8], І. Штулер та інші.

За наявності значної кількості наукових робіт iз питань підприємницької діяльності багато аспектів цієї наукової проблеми залишаються не досить розкритими та обгрунтованими. Потребують подальшого дослідження питання залучення безробітних жінок до організації підприємницької діяльності в Україні.

Метою дослідження є визначення рівня розвитку підприємницької діяльності жінок в Україні та методика залучення безробітних жінок до організації підприємницької діяльності.

Виклад основного матеріалу дослідження. Безробітним, яким виповнилося 18 років та які не можуть бути працевлаштовані за сприяння 
Служби протягом одного місяця у зв'язку з відсутністю на ринку праці відповідної до фаху роботи, за їхнім бажанням допомога з безробіття може виплачуватися одноразово для організації підприємницької діяльності [1]. Для отримання такої виплати клієнту Служби необхідно відвідати консультаційних семінар з основ підприємництва. Далі належить розробити детальний бізнес-план, який дасть змогу оцінити власну бізнес-ідею, зробити відповідні фінансові розрахунки та в результаті довести, що вибрана бізнес-ідея є вдалою, а майбутній бізнес принесе дохід власнику. Розроблення бізнес-плану вимагатиме відвідування експрес-курсу за програмою «Основ підприємницької діяльності та розробоення бізнес-плану», який проходить в Інституті підготовки кадрів державної служби зайнятості в м. Кисві, де професійні тренери в процесі навчання передають свої знання із бізнес-планування і формують відповідні навички, необхідні для ведення та складання бізнес-плану. Після успішного завершення короткострокового навчання клієнт Служби подає власний бізнес-план відповідно до своєї бізнес-ідеї на засідання комісії з питань одноразової виплати допомоги з безробіття для організації підприємницької діяльності, де має отримати позитивну рекомендацію щодо доцільності такої виплати.

В Україні 35\% власників підприємств становлять жінки, а частка жінок-керівників загалом становить 30\% [7]. Більшість жінок-підприємців працюють як фізичні особи-підприємці (ФОП), їхня частка становить 44\%. У 2017 році Державна служба зайнятості долучилася до проекту Програми розвитку ООН «Підтримка реформи соціального сектору в Україні» за напрямом залучення на ринок праці найуразливіших груп населення та жінок. 31 січня 2018 року Програму запроваджено в усіх центрах зайнятості, де спеціалісти центрів індивідуально підходять до проблеми кожної людини, в тому числі жінки, і виявляють, які перепони $\epsilon$ на шляху іiї працевлаштування. За інформацією Служби, кількість зайнятого населення в 2017 році становила 16,2 млн осіб, у 2018 році 16,3 млн осіб, з них відповідно в 2017 році - 48\% (7,7 млн), у 2018 році 48,5\% (7,8 млн) жінки. Рівень зайнятості становив у 2017 році $56, \%$ і $56,8 \%$ у 2018 році, зокрема серед жінок $-51,4 \%$ та 52,4\% відповідно. Станом на 01.12.2018 року послуги держаної служби зайнятості отримали 301 тис. зареєстрованих безробітних, зокрема $57,9 \%$ (174,4 тис.) - жінки [2].

Підприємницька діяльність має неабияке позитивне значення для розвитку особистості, суспільства та держави [8]. Будучи активними підприємцями, матерями та членами суспільства, все ж таки чимало жінок вибирають підприємницьку кар'єру, щоб знайти баланс між роботою та особистим життям за допомогою гнучкого робочого часу. Їхні бізнес-рішення, як правило, дають змогу зберегти такий баланс. У багатьох країнах гендерні стереотипи, культурні традиції або релігійні правила обмежують доступ жінок до освіти та навчання, фінансів і можливостей зайняття бізнесом. Іноді жінкам навіть відмовляють у праві володіти власністю, працювати повний робочий день або займатися підприємницькою діяльністю. У країнах, де це відбувається, урядові та соціальні партнери повинні вирішувати питання створення законодавчих і політичних важелів, які стимулюватимуть залучення жінок до підприємницької діяльності.

Загальновідомо, що вплив ділових жінок на суспільство $€$ значним. Вони $є$ невід'ємною частиною робочої сили, але це не спостерігається в статистиці зайнятості, і чи не найбільше - у підприємництві. Офіційні показники ВВП не відображають часу неоплачуваної жіночої праці щодо сімейного догляду, жінки отримують меншу заробітну плату, ніж їхні колеги-чоловіки, і зазвичай рідше займають керівні посади в компаніях та урядових структурах. За даними Міжнародної фінансової корпорації, у 2012 році жінки становили лише $18,1 \%$ основних власників малих і середніх підприємств у Центральній Азії та Європі [5].

Високий індекс найбільш сприятливих умов $\mathrm{i}$ можливостей для діяльності жінок-підприємців $\epsilon$ у таких країнах, як Нова Зеландія - 74,4; Канада 72,4; США - 69,9; Швеція - 69,6; Сінгапур - 69,5; Бельгія - 69,0; Австралія - 68,5; Філіппіни - 68,4; Велика Британія - 67,9; Таїланд - 67,5. У цих країнах присутні активні спільноти малого і середнього бізнесу, налагоджена нормативно-правова база щодо якості регулювання та ведення бізнесу. Частка жінок-підприємців розподілена таким чином: Уганда - 34,8\%, Ботсвана - 34,6\%, Нова Зеландія - 33,3\%, Росія - 32,6\%, Австрія - 32,4\%, Бангладеш - 31,6\%, В'єтнам - 31,4\%, Китай $30,9 \%$, Іспанія - 30,8\%, США - 30,7\%. Можемо спостерігати, що найбільшим відсоток $€$ у країнах iз низьким рівнем розвитку економіки, де жінки розпочинають власну справу через матеріальні потреби, а не можливості [7].

На жаль, у багатьох країнах бракує централізовано зібраних та оновлених статистичних даних про участь жінок у бізнесі, тому аналіз багато в чому базується на незалежних дослідженнях. Водночас дослідження показують, що серед жінок все більш зростає частка осіб із вищою освітою. Сьогодні 56\% випускників магістратури - жінки. Аналіз, проведений The Economist, свідчить, що з 1970 року жінки заповнили вдвічі більше новостворених робочих місць, ніж чоловіки. Але більшість із них зайняті у фінансовій сфері, і в більшості економік світу кількість жінок-підприємців менша, ніж чоловіків. У доповіді Global Entrepreneurship Monitor за 2004 рік було зроблено 
висновок, що в кожній із досліджуваних країн чоловіки були більш активними у сфері підприємництва, ніж жінки [11]. Найбільший розрив спостерігався у країнах із середнім рівнем доходу, де чоловіки на 75\% частіше, ніж жінки, були активними підприємцями, порівняно з 33\% у країнах 3 високим рівнем доходу та $41 \%$ у країнах iз низьким рівнем доходу.

Незважаючи на те, що жінки, подібно до чоловіків, усе більше усвідомлюють потенціальні можливості підприємництва і вважають це життєздатною альтернативою зайнятості, вони все ж таки внаслідок різноманітних освітніх, культурних та інституційних факторів ще стикаються із значними труднощами та перешкодами стосовно підприємницької кар'єри. Найчастіше такими викликами для жінок-підприємців є культурні традиції та релігійні заборони, відсутність освітніх і навчальних можливостей, системи підтримки бізнесу, доступу до капіталу та інформаційних мереж.

Для успішної підприємницької діяльності чоловіки і жінки фактично потребують однакової підготовки та підтримки, формування основних навичок і компетенцій. Не менш важливим для них $є$ доступ до фінансових можливостей і підтримки державних структур. Підприємництво як вибір кар'єри передбачає ризики і певну свободу у прийнятті рішень. Так, наприклад, у м. Львові підприємницьку діяльність жінок підтримав комерційний банк «Львів», котрий першим в Україні приєднався до ініціативи «Жінки в бізнесі» завдяки міжнародній фінансовій допомозі від Європейського банку реконструкції та розвитку (далі - ЄБРР). Свропейський союз через бізнес-ініціативу EU4 Швецією, Фондом країни раннього переходу ЄБРР та Фондом впливу малого бізнесу СБРР надав фінансовий пакет сумою понад 5,3 млн євро для подальшого кредитування підприємств, котрі очолюють жінки. Кредити видають довгострокові - до 5 років. Така кредитна програма не має обмежень за сумою, яку банк готовий видати одній жінці-підприємцю, та передбачає фінансування малих і середніх підприємств. Нині така програма реалізована у 18 країнах і вже допомогла 55 тисячам жінокпідприємців в отриманні необхідного фінансування свого бізнесу [10].

У бізнесі жінки частіше всього залучаються до створення малих підприємств, вони мають успіх у таких галузях, як дизайн, маркетинг, комунікація, сфери обслуговування, торгівля тощо. Фактично суспільство та професійні спільноти очікують на їхню активність у цих сферах діяльності. Однак жінки мають досить низьку підтримку та можливість, щоб зайняти ті сфери бізнесу, в яких домінують чоловіки (промисловість, юриспруденція, фінанси, будівництво, транспорт, IT-сфера тощо).
Наприклад, за оцінками експертів, кількість жінок, які мають бізнес у сфері науки і техніки в ЄC, становить лише від 5\% до 15\% [5]. В Україні найменш популярною серед жінок є будівельна галузь, робоча сила якої на 80\% складається із чоловіків і лише на 20\% - із жінок. Далі за непопулярністю йдуть транспортна галузь, складське та сільське господарство (відповідно 31,5; 31,6 та $32,5 \%)$, промисловість (38\% від загальної чисельності зайнятих). Натомість типово жіночими $\epsilon$ поштова і кур'єрська діяльність (85,2\% зайнятих у галузі - жінки), сфера охорони здоров'я (82,9\%), робота в бібліотеках, музеях, архівах (78,5\%), сфера освіти $(77,8 \%)$, фінансова та страхова діяльність (72,1\%). Промисловість теж має галузі, у яких переважають жінки. У легкій промисловості 76,4\% зайнятих - жінки, у фармацевтичній галузі кількість жінок становить 59,7\%. Серед видів діяльності, у яких жінки частіше обіймають керівні посади, - туризм (туроператорська діяльність - 61\%, турагентська - 62\%), профспілки та бухгалтерський облік (по 62\%), театральна і концертна діяльність (66\%), освіта у сфері культури (66\%), регулювання у сферах охорони здоров'я, освіти, культури та інших соціальних сферах, крім обов'язкового соціального страхування (68\%), загальна середня освіта (68\%) та надання послуг перукарнями та салонами краси (77\%), які $\epsilon$ не найбільш високооплачуваними галузями.

Висновки. Мотиви до започаткування бізнесу у жінок інші, ніж у чоловіків. Жінки частіше, ніж чоловіки, керуються таким мотивом започаткування підприємництва, як необхідність. Вони часто стають підприємцями через те, що не бачать іншого шляху входження на ринок праці. Жінки також більше від чоловіків цінують гнучкість робочого графіка, можливість збалансувати час між роботою та сімейним життям. Для жінок зростання бізнесу, реалізація ідей для виробництва нового продукту чи надання послуг не такі важливі, як для чоловіків. Але і жінки, і чоловіки прагнуть заснувати прибутковий i сталий бізнес. Провідні міжнародні інституції визначають жіноче підприємництво як дуже важливий чинник економічного зростання. Водночас вони визнають, що кількість жінок, які займаються підприємництвом, значно менша, ніж кількість чоловіків-підприємців. Це стосується і найбільш розвинених країн, включно із країнами «Великої сімки». Одним із найбільш поширених статистичних показників рівня підприємницької активності $€$ самозайнятість. Самозайняті особи визначаються як особи, які володіють власним бізнесом та працюють у ньому. Вони можуть мати або ж не мати найманих працівників [3].

Галузі економіки, у яких працюють жіночі підприємства, як правило, відрізняються від тих, яким віддають перевагу чоловіки-підприємці. 
Самозайняті жінки частіше, ніж чоловіки, працюють у секторі послуг, зокрема в гуртовій та роздрібній торгівлі. Наприклад, у країнах ОЕСР понад 70\% жінок-підприємниць працюють у третинному секторі економіки. Для чоловіків цей показник становить 50\%. Деякі традиційні сектори економіки, в яких розвивається жіноче підприємництво, характеризуються нескладним входженням, високою конкуренцією, низькою продуктивністю та прибутковістю. Переважно жінки самі або з партнерами працюють на своєму власному підприємстві, не будучи роботодавцями. Моделі чоловічого підприємництва дещо інші. Діяльність значної частки самозайнятих чоловіків пов'язана 3 промисловим виробництвом.

Успішне підприємство вимагає таланту, вмотивованості та підприємницьких навичок. Багато успішних жінок мають попередній досвід із менеджменту, здобутий у корпораціях. Опановані ними до цього навички, сформована мережа контактів стають у пригоді під час ведення власного бізнесу.

Крім очевидних переваг, які полягають у створенні нових робочих місць, зниженні рівня безробіття, забезпеченні зростання ВВП та надходжень до бюджету, участі у розвитку місцевої інфраструктури, жіноче підприємництво забезпечує можливості для реалізації підприємницьких, організаційних і творчих здібностей, розроблення та запровадження інновацій, підвищення конкурентоспроможності вітчизняних товарів і послуг. Жіноче підприємництво, передусім мале та середнє, сприяє збільшенню чисельності середнього класу, а значить, зміцненню соціальної та політичної стабільності, сприяє більш швидкому та надійному включенню національної економіки в глобальний простір. Об’єднані в різноманітні асоціації та спілки жінки-підприємці стають реальною владою, здатною чинити вплив на прийняття політичних рішень.

\section{Список використаних джерел:}

1. Закон України «Про загальнообов’язкове державне соціальне страхування на випадок безробіття» (iз змін. $\mathrm{i}$ допов.) від 02 березня 2000 року №1533-III. URL: https://zakon.rada.gov.ua/laws/show/1533-14 (дата звернення 15.03.2020)

2. Аналітична та статистична інформація. Державна служба зайнятості. URL: https://www.dcz.gov.ua/analitics/view (дата звернення 12.03.2020)

3. Аналітичне дослідження «Інклюзивний розвиток бізнесу: жіноче підприємництво». Канадсько-украӥнський проект міжнародної технічної допомоги «Партнерство для розвитку міст» (Проект ПРОМІС). Київ, 2018.136 с.

4. Бутенко Д.С., Довгопола Ю.С. Шляхи розвитку підприємницької діяльності в Україні. Молодий вчений. 2016. № 12 (39). С. 682-685.

5. Видимі та невидимі бар'єри: гендерний аналіз викликів у експортній діяльності для українських мікро-, малих та середніх підприємств (ММСП): звіт. Канадсько-український проект з підтримки торгівлі та інвестицій. Київ, 2019. 56 с.

6. Жінки є власниками 35\% українських компаній. Опендатабот - сервіс моніторингу реєстраційних даних українських компаній та судового реєстру для захисту від рейдерських захоплень і контролю контрагентів. URL: https://opendatabot.ua/blog/175-lovely-woman-day (дата звернення 12.03.2020)

7. Індекс жінок-підприємців від Mastercard виявив умови, необхідні для розвитку жіночого підприємництва. URL: https://newsroom.mastercard.com/eu/uk/news-briefs/index-zhinok-pidpryiemciv-vid-mastercard-vуіаv/ (дата звернення 15.03.2020)

8. Сагайдак Ю. Підприємницька діяльність як основна форма реалізації економічних прав людини. Теоретико-правовий аспект. Підприємництво, господарство і право. 2016. Випуск 7. С. 44-48.

9. Скорук О. В. Стан та проблеми розвитку підприємництва в Україні. Східна Європа: економіка, бізнес та управління. 2016. Випуск 2 (02). С. 107-110.

10. Суспільно-економічне видання «Vezha». URL: https://vezha.net.ua (дата звернення 15.03.2020)

11. Niels Bosma, Netherlands Donna Kelley. Global Report 2003/2004. 152 p. Global Entrepreneurship Monitor. U RL: https://www.gemconsortium.org/ (дата звернення 15.03.2020)

\section{References:}

1. The Law of Ukraine «Pro zagal ’noobov'yazkove derzhavne social`ne straxuvannya na vy`padok bezrobittya» (iz zmin. i dopov.) vid 02 bereznya 2000 roku №1533-III [“On Compulsory State Social Insurance against Unemployment” (as amended) March 2, 2000 1533-III]. URL: https://zakon.rada.gov.ua/laws/show/1533-14 (accessed 15 March .2020).

2. Analytical and statistical information. Derzhavna sluzhba zajnyatosti [State Employment Service]. URL: https://www.dcz.gov.ua/analitics/view (accessed 12 March .2020).

3. Analytical study “Inclusive business development: women's entrepreneurship”. Kanads 'ko-ukrayins `ky”j proekt mizhnarodnoyi texnichnoyi dopomogy` «Partnerstvo dlya rozvy`tku mist» (Proekt PROMIS) [Canadian-Ukrainian project of international technical assistance "Partnership for Urban Development" (PROMIS Project)]. Kyiv, 2018.

4. Butenko D.S., Dovgopola Yu.S. Shlyaxy` rozvy`tku pidpry`yemny`cz'koyi diyal’nosti v Ukrayini [Ways of business development in Ukraine]. Molody`j vcheny`j [Young scientist]. 2016. № 12 (39). P. 682-685.

5. Vy`dy`mi ta nevy`dy`mi bar'yery`: genderny`j analiz vy`kly`kiv u eksportnij diyal'nosti dlya ukrayins`ky`x mikro-, maly`x ta serednix pidpry`yemstv (MMSP): zvit. Kanads`ko-ukrayins`ky`j proekt z pidtry`mky` torgivli ta investy`cij [Visible and Invisible Barriers: Gender Analysis of Export Challenges for Ukrainian Micro, Small and Medium-Sized Enterprises (MSMEs): Report. Canadian-Ukrainian Trade and Investment Support Project]. Kyiv, 2019. 56 p.

6. Zhinky ye vlasny'kamy`35\% ukrayins'ky`x kompanij [Women own 35\% of Ukrainian companies]. Opendatabot - servis monitory`ngu reyestracijny`x dany`x ukrayins`ky`x kompanij ta sudovogo reyestru dlya zaxy`stu vid rejders`ky`x zaxoplen` 
$\mathrm{i}$ kontrolyu kontragentiv [Oppendabot is a service for monitoring the registration data of Ukrainian companies and the court registry to protect against raids and control of counterparties]. URL: https://opendatabot.ua/blog/175-lovely-woman-day (accessed 12 March .2020).

7. Indeks zhinok-pidpry`yemciv vid Mastercard vy`yavy`v umovy', neobxidni dlya rozvy`tku zhinochogo pidpry`yemny'cztva [The Mastercard Index of Women Entrepreneurs identified the conditions necessary for the development of women's entrepreneurship]. URL: https://newsroom.mastercard.com/eu/uk/news-briefs/index-zhinok-pidpryiemciv-vid-mastercard-vyiav/ (accessed 15 March .2020).

8. Sagajdak Yu. Pidpry`yemny 'cz 'ka diyal’nist`yak osnovna forma realizaciyi ekonomichny`x prav lyudy`ny` [Entrepreneurial activity as the main form of realization of economic human rights]. Teorety`ko-pravovy`j aspekt. Pidpry`yemny'cztvo, gospodarstvo i pravo [Theoretical and legal aspect. Entrepreneurship, economy and law]. 2016. Vol. 7. P. 44-48.

9. Skoruk O. V. Stan ta problemy` rozvy`tku pidpry`yemny cztva v Ukrayini [The state and problems of entrepreneurship development in Ukraine.]. Sxidna Yevropa: ekonomika, biznes ta upravlinnya [Eastern Europe: Economy, Business and Management]. 2016. Vol. 2 (02). P. 107-110.

10. Suspil`no-ekonomichne vy`dannya «Vezha» [Vezha socio-economic publication]. URL: https://vezha.net.ua (accessed 15 March .2020).

11. Niels Bosma, Netherlands Donna Kelley. Global Report 2003/2004. 152 p. Global Entrepreneurship Monitor. URL: https://www.gemconsortium.org/ (accessed 15 March .2020).

Plysenko Galina

Ukrainian State Employment Service Training Institute

\section{WOMEN'S ENTREPRENEURSHIP IN UKRAINE AND THE WORLD AS AN ELEMENT OF TRANSFORMATION OF QUALITY AND STRUCTURE OF THE WORKFORCE}

The article highlights the issues of women's entrepreneurship in Ukraine, the current business environment and the possibility of own business setting up were analyze and summarized. The statistics of female entrepreneurship in some foreign countries were consider. The purpose of the research is to determine the possibility of opening and conducting business activities by women in the realities of Ukrainian society. The research used general scientific and special methods: scientific generalization and systematization; comparative and system analysis; logical synthesis.

Research of current trends in women's entrepreneurship in Ukraine afforded grounds to justify business setting up. Was establish that the current conditions of doing business in Ukraine were characterize by unfavorable fiscal, monetary and regulatory policies of the state. It was determined that one of the active forms of support for the unemployed, which is carried out by the state employment service in the absence of proper work in the labor market, is the involvement of the unemployed in the organization of business activity. It was prove that women's participation in business transforms the quality and structure of the workforce and society as a whole, promotes women's career development, self-fulfillment and creation of new workplaces. It affects their households and communities, shaping the thinking of future generations that can inspire self-employment as a natural career option. It was substantiate that women have significant employment potential that can be realize through training and support, which is one of the key factors for enhancing their business activity. This in turn can improve the economic efficiency of employment and ensure the creation of new workplaces.

In addition to the obvious advantages of creating new jobs, reducing unemployment, securing growth in domestic gross domestic product and budget revenues, participating in local infrastructure development, women's entrepreneurship provides opportunities for entrepreneurial, organizational and creative skills, development and innovation, enhancing the competitiveness of domestic goods and services.

Key words: women, entrepreneurship, business, labor market, employment, employment service.

JEL classification: J01, J6, J16, J21, J24. 